\title{
DIAGNOSING ORGANIZATIONAL CULTURE IN NATIONAL AND INTERCULTURAL CONTEXT
}

\author{
Milota Vetráková, Lukáš Smerek
}

\section{Introduction}

There is almost no area of life and industry, which would not face the new challenges of globalization. Organizations operating in Slovakia are not an exception. Globalization is the process of international integration arising from the interchange of all areas (economics, politics, culture, communication, environment, etc.) observed especially in recently (Orieška 2009 , p. 131). It is a process of unification of countries, their cultures and economies, monetary units, the process of creating greater competitive units.

For Horner and Swarbrook (2003, p. 443) globalization exists because of the fact that some companies operate worldwide on a larger scale and sell their products in more homogeneous global market. By Teo and HiongLi (2003, p. 289) globalization is linked with more powerful networks, flows, transactions, images and ideas that cross and link states and companies. It does not cover only the geographically spread activities behind territorial boundaries, but the functional integration of internationally dispersed economic, social and political activities is more important. As Pichanič noted (2004, p. 11), people are exposed to global culture, global economy and global environmental change to the extent we have not known before.

Baláž (2010) evaluates the process of globalization as the most important form of unification of countries into common units characterized by opened markets for trade and entry of foreign investment. A positive result is pressure to improve the quality, rapid spread of modern technology, the promotion of modern management methods, and greater mobility of production factors. On the other hand, local, regional and national cultural particularities are disappearing. While proper attention in the theory and practice in devoted to environmental changes due to global economy, exploring global culture is marginalized. However, in a global environment, the managers and other staff deal with people from different cultures, who bring a number of specific communication elements and expression in the communication process that can be a source of noise and misunderstanding. Not only the foreign language is the means of communication among people of different cultures, but above all the ability to create such a process of cooperation and communication that will be understood by all concerned. Intercultural communication is based on the exchange of ideas, objects, values, and meanings of information between members of different cultures.

To understand the others, we have to know, first of all, our own culture and differences in other cultures and find common elements that bring people together, not separate (Vetráková in Olejárová et al., 2007, p. 15). Many managers working in another country have prejudices associated with the national culture of the country. Instead of taking the challenges of working in an intercultural setting and focusing on finding common values and goals, they deal with differences.

International setting, in which the cultures in the globalization process got, is completely different from traditions from which national cultures historically evolved. The most common setting (environment) in which members of different cultures work and live together is multicultural or intercultural. A common feature of multicultural and intercultural setting (Sadri \& Flamme, 2011, p. 8) is cooperation and tolerance of different cultures. International teams work in multinational companies and corporations at the international level, management of companies is international. Organizational culture of companies is the impact of power politics or the result of consolidation and 
acceptance of cultural differences in a common culture. Multiculturalism and interculturalism are misunderstood, especially in the countries and companies which politics and economics are ethnocentric and traditionalist.

\section{Diagnosing Organizational Culture}

Culture is defined as the accumulation of spiritual and material values created and generated by mankind throughout its history. Despite different approaches to defining culture, there is consent in the preferred common values or specific behaviors or collective programming of the mind through which one group differs from the other (Matsumoto \& Juang, 2007; Sagiv \& Schwartz, 2007; Aydin \& Ceylan, 2009).

Each person in the life belongs to several social groups and meets with different cultural patterns, which determine him. In the case that different cultures have different levels of cultural basis, misunderstandings and various conflict situations can occur. Therefore, exploring and understanding the value characteristics and cultural differences (Hofstede, 2001; Reisinger, 2010; Trompenaars \& Hampden-Turnes,
2007 and others) is a prerequisite for effective work and communication in the national and intercultural setting.

National culture creates an individual belonging to a country, to a certain nation. According to Hofstede and Hofstede (2005, p. 14) it corresponds to the country from which the individual comes. Individual behavior is seen in relation to the nation, a social group and the organization in which he works and vice versa. Each of the components in which the individual exists has its rules, which are reflected in the established and accepted values and beliefs. Particular communications in national cultures are influenced by differences in behavior and are shown in the style and context of communication, interpersonal relationships, in the action, customs and rituals (Bringkmann \& Weerdenburg, 2014; Guirdham, 2011; Tsui, Nifadkar \& Oh, 2007). National culture is the basis for the formation of organizational culture in organizations operating in the territory of the country. The multinational organizations and corporations take into account the influence of cultures of several nations in the organizational culture.

\section{Tab. 1: Elements of organizational structure}

\begin{tabular}{|c|c|c|c|c|}
\hline & \multicolumn{2}{|c|}{ Factors acting externally } & \multicolumn{2}{|c|}{ Factors in organization } \\
\hline & immaterial & material & immaterial & material \\
\hline Artefacts & $\begin{array}{l}\text { image } \\
\text { presentation of vision } \\
\text { and philosophy of } \\
\text { organization }\end{array}$ & $\begin{array}{ll}\text { - } & \text { products } \\
\text { - } & \text { design } \\
\text { - } & \text { logo } \\
\text { - } & \text { modvertisement } \\
\text { - } & \text { organizational } \\
& \text { colours } \\
\text { - } & \text { buildings } \\
\text { - } & \text { architecture } \\
\text { identification of } \\
\text { management } \\
\text { functions }\end{array}$ & $\begin{array}{ll}\text { - } & \text { language used } \\
\text { - } & \text { stories and myths } \\
\text { - } & \text { customs } \\
\text { - } & \text { heroes } \\
\text { - } & \text { rituals } \\
\text { - } & \text { ceremony } \\
\text { - } & \text { valuing employees } \\
\text { - } & \text { employee status }\end{array}$ & $\begin{array}{ll}\text { - } & \text { working environment } \\
\text { - } & \text { furnishings } \\
\text { - } & \text { promotional items } \\
\text { - } & \text { working conditions } \\
\text { - } & \text { clothes of employees } \\
\text { - } & \text { employee benefits }\end{array}$ \\
\hline $\begin{array}{l}\text { Norms } \\
\text { and values }\end{array}$ & $\begin{array}{ll}\text { - } & \text { organization strategy } \\
\text { - } & \text { negotiations on market } \\
\text { - } & \text { negotiating with } \\
\text { - } & \text { business partners } \\
\text { communication with } \\
\text { customers }\end{array}$ & $\begin{array}{ll}\text { - } & \text { code of ethics } \\
\text { - } & \text { sustainable } \\
\text { development } \\
\text { - } \\
\text { corporate social } \\
\text { responsibility }\end{array}$ & $\begin{array}{ll}\text { - } & \text { management style } \\
\text { - } & \text { working } \\
\text { - } & \text { atmosphere } \\
\text { - } & \text { codes of conduct } \\
\text { and relationship in } \\
\text { the workplace }\end{array}$ & $\begin{array}{ll}\text { - } & \begin{array}{l}\text { organizational } \\
\text { structure }\end{array} \\
\text { - } & \begin{array}{l}\text { regulations and } \\
\text { documents of }\end{array} \\
\text { organization } \\
\text { - informal norms }\end{array}$ \\
\hline
\end{tabular}


Organizational culture defines belonging of individuals to the organization in which they work. The term of organizational culture is known since the mid nineteen eighties (Karlöf, Lövingsson, 2006). Several authors deal with it (Kotter \& Heskett, 2001; Hitka et al., 2010; Sackmann, 2006; Mitrovič et al., 2014 and others), while each of them emphasizes different attribute of behavior and actions of people and ways of work performance. Therefore, we are looking for basic building components of the cultural organization which are its elements. Basic assumptions, values, norms, and artifacts are considered the most common elements in the organizational culture (Tab. 1).

Despite differences of opinion on the definition of organizational culture, we note that there is a set of basic assumptions, values, attitudes and norms of behavior that are acquired in the organization and are shown in the artifacts of material and non-material nature of thinking, feeling and behavior its members. Organizational culture is symbolized by "a summary of customs, values, policies, expectations and attitudes that create conditions for behavior and thinking in the organization" (Dědina \& Cejthamr, 2005, p. 265). Organizational culture provides an opportunity to individuals to justify their behavior in response to the preferred values of the organization. By Blašková (2009) organizational culture reflects the motivational attributes of employees and managers. It is a mosaic of their needs, expectations, aspirations and will.

Behavior of individuals is influenced not only by organizational culture, but also by the cultures of several nations. People of different cultures work in transnational organizations whose value orientation and behavior patterns are different. Communication in organizations with international presence requires a greater degree of communication skills, the ability to assess the needs of the partner and recognize cultural differences that may affect the process of subsequent cooperation. National culture becomes a criterion which refers to itself, because no other culture is identical to ours. "We use national intercultural assessment and our own culture as a standard under which we compare and make judgments about what is similar to our culture is normal and good, on the other hand, what is different is considered abnormal and wrong" (Adler, 2008, p. 86). In contact with members of other cultures, we tend to judge and evaluate other cultures as lower or less valuable. This limited evaluation and evaluative judgments does not help in the effort to understand, communicate and collaborate with people from other cultures, but causes communication misunderstandings.

To understand cultural differences in national and intercultural setting it is necessary to identify the current state of organizational culture, which may vary according to the prevailing approaches to the management of multinational companies. Three management approaches developed by Robbins and Coulter (2004, p. 113) can be applied in shaping organizational culture: ethnocentric (confidence in the fatherland), polycentric (confidence in the country where the organization is located) and geocentric (world-oriented focus). According to Martin and Fellenz (2010, p. 509) "transnational type of organization brings together global integration, local differences and global innovation". Integrated network of all available resources and products is used to benefit the organization as a whole. Formation of jointly accepted organizational culture and management system helps managers from different cultures to overcome barriers in communication and mutual cooperation across national borders.

Problems of communication in intercultural environment in the literature (Olejárová et al., 2007; Minkov, 2007; Průcha, 2010; Gertsen, Soderbery \& Zolner, 2012; Brinkmann \& Weerdenburg, 2014; etc.) is described in general and from the perspective of trade negotiations or particulars of different cultures in the behavior of individuals. Awareness of the competences and skills of managers in intercultural setting is low. There is not a diagnosis of organizational culture and its connection to the Slovak and intercultural environment. Diagnosis is one of the methods to examine organizational culture (Šigut, 2004). The aim is to describe concisely the elements of culture accepted in the organization, to analyze causes of the existing situation in order to implement the desired changes in the interests of management and employees.

Organizational culture reflects the history and current situation of an organization, brings together ideas of employees with ideas and expectations of management. It is the object of extensive research abroad for several decades. Approaches of examination, diagnosing 
organizational culture can be classified into three groups:

a) Dimensional approaches (Hofstede \& Hofstede, 2005; Sagiv \& Schwartz, 2007).

b) Interrelated approaches (Homburg \& Pflesser, 2000; Deshpandé \& Farley, 2004).

c) Typological approaches (Deal \& Kennedy, 2000; Goffee \& Jones, 2003; Cameron \& Quinn, 2006).

Dimensional approaches focus mainly on empirical measurement of organizational culture, as (in some cases, bipolar) scales, which may be associated with other, mostly dependent variables (Tsui, Nifadkar \& Oh, 2007). Interrelated approaches link the concept of organizational culture with other features of the organization and often represent the theoretical basis of the proposals for empirical research (Reisinger, 2010). Typological approaches are based on pre-defined key characteristics that are divided and brought together by organizations in certain categories. By Armstrong and Stephens (2008) the type of organizational culture gives sense of identity and unity of purpose, sets the stage for action within the organization, strengthens the commitment of employees, forms behavior, brings the needs and expectations of employees and managers.

Typological approaches are the most discussed while most cited. We realize that every typology is simplified and schematic, it does not cover the root of the problem, on the other hand, it creates a space for comparison and searches for ways to improve. The discussion is aimed at the precise definition of empirical features and different limitations of classification. Based on the study of literary sources at home and abroad, the most cited international authors who present different types of organizational culture are Cameron and Quinn (2006). Their typology presents a framework of conflicting values, which describes four types of organizational culture - the clan, adhocracy, hierarchy and market, based on the dimensions of flexibility/stability and with internal / external focus (Fig. 1). The upper left quadrant represents a clan culture. The organization of this culture is characterized by flexibility and orientation inside. The management is friendly to customers and employees, and often creates a sense of family environment. Clan culture has high morale and members are satisfied with the current state of the organization.

Adhocratic culture is flexible, with an external focus. Work teams arise and vanish quickly because of rapidly changing external conditions. Members are flexible, creative and confident in dealing with ambiguous situations. Employees easily handle different situations and flexibly respond to changing market needs. Changes in organizational structure are common expected by staff.

Hierarchy culture is internally focused and emphasizes centralized control and management. This type of culture often involves bureaucratic institutions such as governments, public administration based on the rules and emphasize strict compliance with policies and procedures with an emphasis on efficiency and smooth operation. Organizations with such culture respond to known problems effectively, but they are not able to meet the unique situation.

The last type of culture is a market culture that prefers centralized management of the openness of the external environment. It encourages employees to be productive and competitive in the measurement of work performance and achieving sales growth. Results of employees are often compared with each other (Schimmoeller, 2010).

Choosing the type of organizational culture is the result of a consensus of managers and employees. There is nothing unusual if individual departments have their own subculture (Deal \& Kennedy, 2000). However, we don't agree with a view (Alvesson, 2002) that the organizational culture is either good or bad. Each organizational culture is important to achieve certain stability and respect the basic assumptions, values and norms (Seková et al., 2013, p. 144).

\section{A Survey of Organizational Culture in Slovakia}

A survey aimed at diagnosing different types of organizational culture in companies with national and international participation in Slovakia was conducted. The result of the examination is to identify positive and drawbacks of different types of organizational culture in the development of human resources. Identification of organizational culture was done by Cameron and Quinn (2006), because their diagnosis complies with the goals of the investigation. 


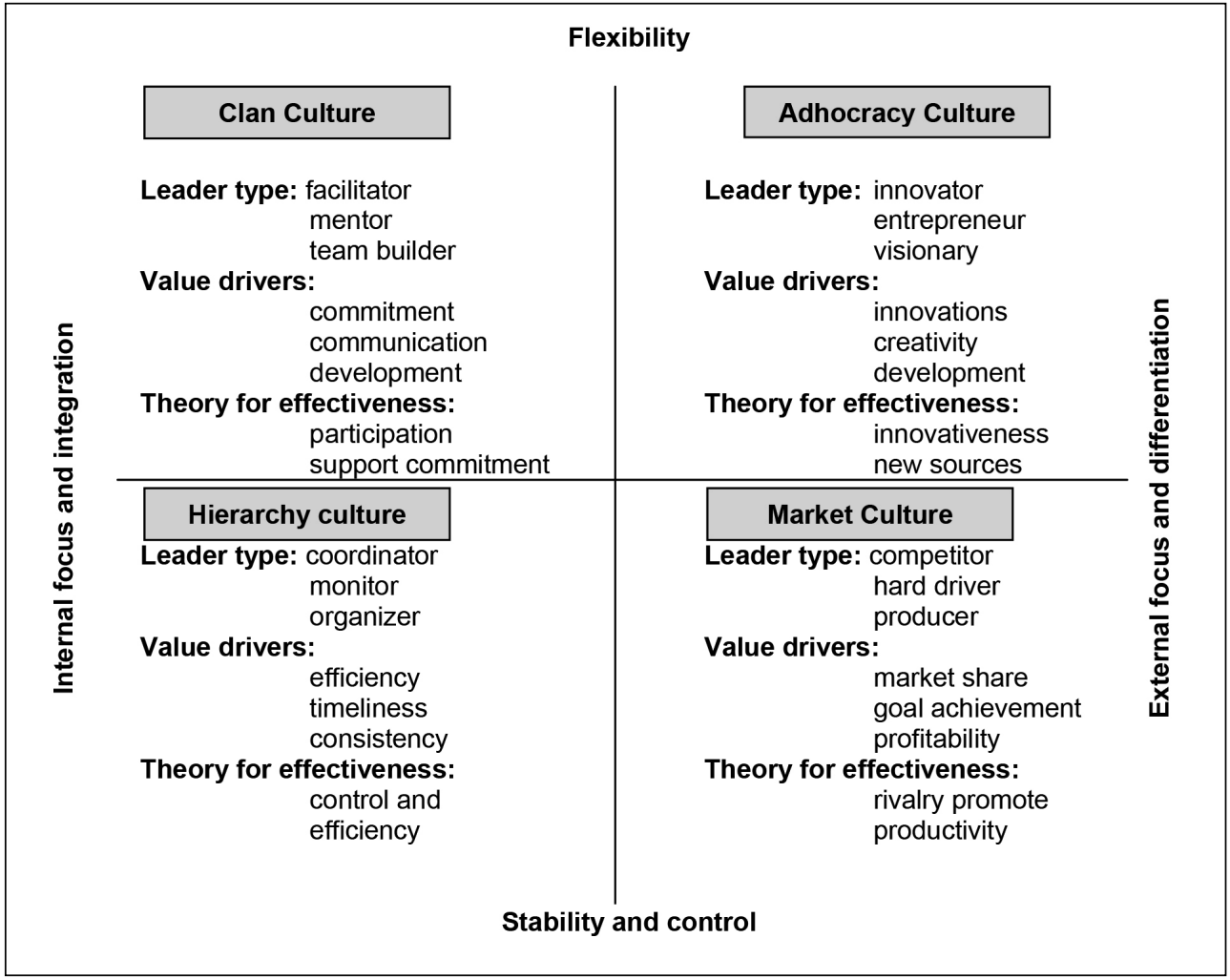

The choice is suitable also because the need and importance of organizational culture which can be quantified is considered as important by listed authors.

\subsection{Research Methodology}

The research is based on the main hypothesis $\mathrm{HO}$ that the existing organizational culture in most of the surveyed companies does not support human resource development. The main hypothesis is verified in sub-hypotheses:

$\mathrm{H} 1$ : we can diagnose all types of corporate culture,

$\mathrm{H}$ 2: the impact of organizational culture on human resource development is different in companies with international participation and without it,

H3: the impact of different types of organizational culture on human resource development grows in the direction of line through the market and adhocracy to the clan culture.

The basic method of verification of stated assumption is sociological interview using a questionnaire. The questionnaire consisted of 28 questions. In the first part we identify organizational culture using OCAI Organizational Culture Assessment Instrument. In the second part we find information on the impact of organizational culture on human resources. We focus on the tools and methods of their application in the surveyed enterprises. To identify the organizational culture we will also focus on issues of foreign participation in the development of the cultural environment and compare the types of cultures prevailing in Slovak enterprises and enterprises with international presence. 
Survey was preceded by a preparatory phase of the suitability of the selected methodology conducted in October to December 2013. Medium and large enterprises operating in the Slovak Republic were included in the survey carried out in 2014. The basic sample consists of 2,660 medium and 624 large enterprises (3,284 together). Data collection was carried electronically using available mail resources or personally. 1,396 staff or executives of enterprises were addressed.
236 responses were filled correctly, which means $16.55 \%$ return. The sample consisted of 182 medium and 54 large enterprises.

Prior to evaluating the questionnaire we verified the representativeness of the sample according to the site of action (Tab. 2) and company size (Tab. 3) using goodness of fit test with a significance level of $\alpha=0.05$. Found results can be generalized to the entire core set only in the case of a representative set.

\section{Tab. 2: Classification of basic and sample set by regions}

\begin{tabular}{l|c|c|c|c|c}
\multicolumn{1}{c|}{ Region } & \multicolumn{2}{c|}{ Basic set } & \multicolumn{2}{c}{ Sample set } & Deviation \\
\hline Bratislavský & 958 & $29.17 \%$ & 75 & $31.78 \%$ & 6.2 \\
\hline Trnavský & 314 & $9.56 \%$ & 17 & $7.20 \%$ & -5.6 \\
\hline Trenčiansky & 359 & $10.93 \%$ & 28 & $11.86 \%$ & 2.2 \\
\hline Nitriansky & 379 & $11.54 \%$ & 20 & $8.48 \%$ & -7.2 \\
\hline Žilinský & 391 & $11.91 \%$ & 28 & $11.86 \%$ & -0.1 \\
\hline Banskobystrický & 281 & $8.56 \%$ & 26 & $11.02 \%$ & 5.8 \\
\hline Prešovský & 319 & $9.71 \%$ & 26 & $11.02 \%$ & 3.1 \\
\hline Košický & 283 & $8.62 \%$ & 16 & $6.78 \%$ & -4.3 \\
\hline \multicolumn{7}{c|}{ Total } & $\mathbf{3 , 2 8 4}$ & $\mathbf{1 0 0 . 0 0 \%}$ & $\mathbf{2 3 6}$ & $\mathbf{1 0 0 . 0 0 \%}$ & \\
\hline \multicolumn{7}{c|}{} & & & & \\
\hline Chi-square statistics & 7.039 & & & & \\
\hline Degrees of freedom & 7 & & & & \\
\hline P-value & 0.425 & & & & \\
\hline
\end{tabular}

Source: Based on data from the Statistical Office of the Slovak Republic on 31st March 2014 and the results of the questionnaire.

\section{Fig. 2: Slovak regions}

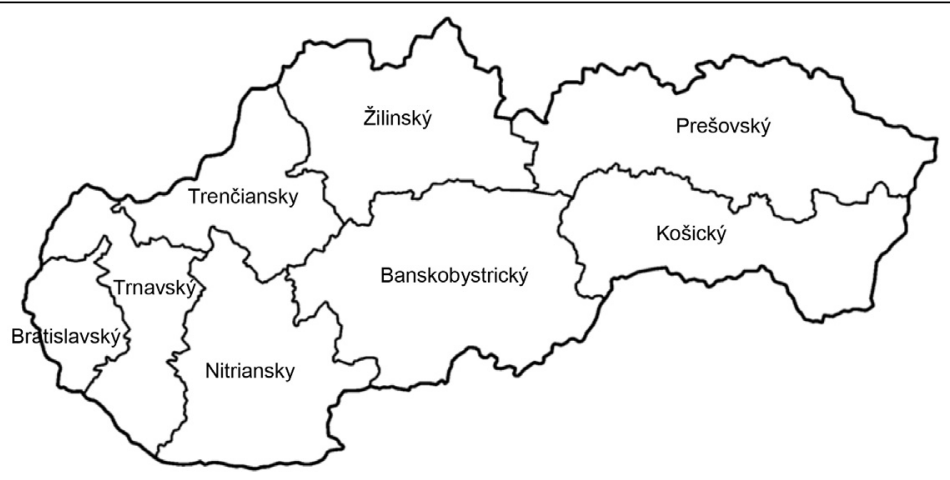

Source: own processing 
Tab. 3: Classification of basic and sample set by size

\begin{tabular}{|c|c|c|c|c|c|}
\hline Size of enterprise & \multicolumn{2}{|c|}{ Basic set } & \multicolumn{2}{|c|}{ Sample set } & \multirow{2}{*}{$\begin{array}{c}\text { Deviation } \\
-9.2\end{array}$} \\
\hline Small (50-249 employees) & 2,660 & $81.00 \%$ & 182 & $77.12 \%$ & \\
\hline Large (> 249 employees) & 624 & $19.00 \%$ & 54 & $22.88 \%$ & 9.2 \\
\hline Total & 3,284 & $100.00 \%$ & 236 & $100.00 \%$ & \\
\hline \multicolumn{6}{|c|}{ Test statistics } \\
\hline & Size & & & & \\
\hline Chi-square & 2.310 & & & & \\
\hline Degree of freedom & 1 & & & & \\
\hline P-value & 0.129 & & & & \\
\hline
\end{tabular}

Source: based on data from the Statistical Office of the Slovak Republic on 31st March 2014 and the results of the questionnaire

Tab. 4: Number of enterprises by organizational structure

\begin{tabular}{|c|c|c|c|c|c|c|c|c|}
\hline \multirow{4}{*}{$\begin{array}{l}\text { Culture } \\
\text { Clan }\end{array}$} & \multicolumn{8}{|c|}{ Number of enterprises } \\
\hline & \multirow{2}{*}{\multicolumn{2}{|c|}{ Altogether }} & \multicolumn{6}{|c|}{ Leadership } \\
\hline & & & \multicolumn{2}{|c|}{ Slovak } & \multicolumn{2}{|c|}{ mixed } & \multicolumn{2}{|c|}{ foreign } \\
\hline & 77 & $32.63 \%$ & 40 & $28.78 \%$ & 32 & $38.55 \%$ & 5 & $35.71 \%$ \\
\hline Adhocracy & 24 & $10.17 \%$ & 18 & $12.95 \%$ & 6 & $7.23 \%$ & 0 & 0 \\
\hline Market & 47 & $19.91 \%$ & 18 & $12.95 \%$ & 24 & $28.92 \%$ & 5 & $35.71 \%$ \\
\hline Hierarchy & 88 & $37.29 \%$ & 63 & $45.32 \%$ & 21 & $25.30 \%$ & 4 & $28.58 \%$ \\
\hline Total & 236 & $100 \%$ & 139 & $100 \%$ & 83 & $100 \%$ & 14 & $100 \%$ \\
\hline
\end{tabular}

Source: own processing

Goodness of fit test shows that $p$-value equals to $0.425>0.05$, which means confirmation of the sample set by region. Goodness of fit test was also applied to determine the representativeness of the group by company size. P-value of 0.129 at the chosen significance level of 0.05 confirms the compliance of the distribution of the sample by the size of the basic set.

The results obtained in primary research were verified using the Delphi method. The Delphi method is considered as the method of collecting expert views through repeated interviews with controlled feedback. Eight experts professionally engaged in the management of human resources and corporate culture participated in the examination. Four experts were from the academic setting and four working on the position of HR managers or executives. In order to ensure their anonymity, each respondent answers independently and do not state their identity.

\subsection{Results and Discussion}

There is not yet a great experience with diagnosing organizational culture in Slovakia. In the first phase, respondents were asked to diagnose the type of organizational culture - the clan, adhocracy, market and hierarchy. Each of these cultures differ from the others in 6 dimensions, which are the general characteristics of company, leadership in business, managing the work of employees, corporate cohesion, strategic focus and success criteria. The task of respondents was 
to assign to each dimension a corresponding number of points out of 100 at the type of culture that is closest to the situation in the company in which they work. Subsequently, totaling the values for each option A-D and application of the arithmetic mean, we got four coordinates that determine the type of organizational culture in the enterprise. As OCAI divides types of corporate cultures by dimensions (internal / external focus and flexibility / control) we also take into account this fact in the calculations. The procedure was applied for each surveyed business. The result of organizational culture types is in Table 4.

We identified all four types of organizational culture in the surveyed companies in Slovakia. The results of diagnosis showed the differences between the types of organizational culture prevailing in Slovak enterprises and enterprises whose leadership is foreign or mixed. Hierarchy culture is dominated in Slovak enterprises, while the clan and market culture in companies with international presence. A typical feature of hierarchy culture is security and control, which guarantees smooth functioning. Reasons of dominant hierarchy culture should be examined further since they probably are connected with our traditions, the impact of national culture, the historical, economic and political developments and the types of industry. Hierarchy culture was identified in 30 industrial, 12 constructing and 11 engineering companies out of 88 involved.

Organizational culture gradually changed with expansion of multinational companies which was confirmed in the survey conducted. Work in a multicultural environment is also reflected in changed management system. Clan culture is typical for companies with mixed or foreign leadership, followed by a market culture. The clan culture is characterized by flexibility, mutual solidarity, cohesion, morale, and the emphasis is put on the development of human resources. Companies of clan culture are dominant in services, trade and information technology. Criteria for efficiency in market culture are competition, mutual rivalry and power. The main aim is to achieve the objectives, increasing market share and meet the competition. Not every employee has the capacity to handle a job in this challenging competitive environment, those strong will win.

Set of closed questions (18) were used in the second part of the sociological interview to establish human resource development. We formulated the questions in order to identify instruments of human resource development. Each of the responses was judged by the number of points. To assess the degree of development Likert scale was used. To verify the statistical dependence between organizational culture and level of development of human resources, we selected Pearson chi-square test. P-value is close to 0 , for significance level $\alpha=0.05$ the argument that the type of organizational culture and level of development of human resources are independent was rejected and therefore to test the strength of dependence between them is useful. Phi and Cramer's V coefficient was chosen to test the power of addiction. The more the values are close to 1 , the stronger the relationship between the monitored variables is. There is relatively strong dependence between the types of organizational culture and level of human resource development. The results were verified by one-way analysis of variance (ANOVA). Hierarchy and market culture pay equal attention to development of human resources. On the contrary, adhocracy and clan culture the impact on human resource development is intensive.

We consulted the findings on the impact of organizational culture on human resource development with experts, using delphi method. Opinions on examined issues obtained in the first stage were summarized with majority (75-100\%) agreement. In the second stage, we included questions with greater range of views. There are some of the conclusions:

- Diagnosing culture by OCAI methodology showed the presence of all types of organizational culture in Slovakia, the majority of enterprises with a hierarchy culture.

- Organizational culture affects performance, employee satisfaction, regulates the relations of superiority and subordination, defines powers.

- National culture and tradition influence the form of organizational culture through values and norms. The most common problems, which may arise, are the conflict of values and norms, and too much effort to promote their own values and standards.

- Development of human resources depends on existing organizational culture.

- Human resource development is influenced by the values and managers - leaders at 
best from all elements of organizational culture.

- The precondition for successful change of organizational culture is mainly awareness of the need for change on the company management level, order and careful selection of individual steps and a high emphasis on communication purposes, goals, objectives and methods of changes between management and employees.

- The main pitfalls of organizational culture change are lack of understanding among staff and resistance to change, based on the natural fear of the unknown.

- Higher level of human resource development is in companies with international presence and more flexible organizational culture, since flexibility means the need for constant change and innovation. It is a determinant of human resource development.

- Identified causes in hierarchy organizational culture, which supports human resource development the least, include the impact of national culture, the historical development of economic, social and political environment in Slovakia and types of industry in Slovak companies.

The degree of credibility of findings based on questionnaires and diagnosing organizational culture according to Cameron and Quin was also confirmed by the experts using the Delphi method. We are aware of certain limitations in each of our sociological questionnaires. However, we believe that the combination of two techniques of collecting information the validity and reliability of adopted conclusions was increased. Organizational culture is not dogma, it develops gradually as the changing mindset of people and their approaches and insights into reality.

\section{Conclusion}

Organizational culture reflects the thinking and behavior of people, affects the interpretation of the situation, it is a reflection of the past and present. In terms of achieving the strategic goals it is important to accept it and further develop. Diagnosing is one way that helps managers and owners to find out the current organizational culture in order to describe its features, find the causes of the existing problems in the workplace and to take the necessary measures to change. Each culture has its advantages and drawbacks. For managers and business owners, it is important to implement such a type of organizational culture, which best corresponds to ideas and opportunities of employers and employees. Hierarchy culture, which is dominant in Slovakia, is characterized by a structured working environment, preferred laws, rules and operating procedures. Managers aim to achieve steady running of companies without major changes, giving security and safety to employees. On the contrary, organizational culture supporting change and flexibility are represented by greater dynamism, creativity and openness to new challenges.

The survey results present the first stage of the examination of organizational culture and open space for scientific discussion on shaping organizational culture in the national and intercultural space. The degree of credibility findings based on questionnaires and diagnosing organizational culture according to Cameron and Quin was also confirmed by the experts in the context of using the Delphi method. Clearer and deeper conclusions about the impact of the type of organizational culture on human resource development, readiness of managers and other staff to work in a multicultural area requires further investigation, in which we will continue in the research project VEGA "Formation of organizational culture and management system of enterprises with international presence in intercultural environment".

\section{References}

Adler, N.J. (2008). International Dimensions of Organizational Behavior. Mason: Thomson Higher Education.

Alvesson, M. (2002). Understanding Organizational Culture. Trowbridge: The Cromwell Press Ltd.

Armstrong, M., \& Stephens, T. (2008). Management a leadership. Praha: Grada Publishing.

Aydin, B. \& Ceylan, A. (2009). The Role of Organizational Culture on Effectiveness. E\&M Ekonomie a Management, 12(3), 33-49.

Baláž, P., et al. (2010). Medzinárodné podnikanie. Bratislava: Sprint.

Blašková, M. (2009). Correlations between the Increase in Motivation and Increase in Quality. E\&M Ekonomie a Management, 12(4), 54-68. 
Brinkmann, U., \& Weerdenburg, O. (2014). Intercultural Readiness. Four competences for working across cultures. Hampshire: Palgrave Macmillan.

Cameron, K., Quinn, R. (2006). Diagnosing and Changing Organizational Culture. Based on the Competing Values Framework. San Francisco: Jossey-Bass.

Deal, T.E., \& Kennedy, A.A. (2000). The New Corporate Cultures: Revitalizing the work place after downsizing, mergers and reengineering. London: TEXERE Publishing Limited.

Dědina, J., \& Cejthmar, V. (2005). Management a organizační chování. Praha: Grada Publishing.

Deshpandé, R., \& Farley, J.U. (2004). Organizational Culture, market orientation, innovativeness, and firm performance: An international research odysey. International Journal of Research in Marketing, 21(1), 3-22. doi:10.1016/j.ijresmar.2003.04.002.

Gertsen, C.M., Soderber, A.M., \& Zolner, M. (2012). Global Collaboration: Intercultural Experiences and Learning. Hampshire: Palgrave Macmillan.

Goffee, R., \& Jones, G. (2003). The Character of a Corporation: How Your Company's Culture Can Make or Break Your Business. London: Profile Books.

Guirdham, M. (2011). Communicating across Cultures at Work. Hampshire: Palgrave Macmillan.

Hitka, M., et al. (2010). Podniková kultúra $\checkmark$ riadení ludských zdrojov. Zvolen: Technická univerzita vo Zvolene.

Hofstede, G. (2001). Culture's Consequences: Comparing Values, Behaviours, Institutions and Organisations across Nations. London: SAGE Publications.

Hofstede, G., \& Hofstede, G.J. (2005). Cultures and Organizations: Software of the Mind. New York: McGraw-Hill Ryerson.

Homburg, C., \& Pflesser, C. (2000). A multiple-layer model of market-oriented organizational culture: Measurement issues and performance outcomes. Journal of Marketing Research, 37(4), 449-462. doi:10.1509/ jmkr.37.4.449.18786.

Horner, S., \& Swarbrook, J. (2003). Cestovní ruch, ubytování a stravování, využití volného času. Praha: Grada Publishing.

Kachaňáková, A. (2010). Organizačná kultúra. Bratislava: IURA Edition.

Karlöf, B., \& Lövingsson, F.H. (2006).
Management od A do Z. Brno: Computer Press.

Kotter, J., \& Heskett, J. (2001). Corporate Culture and Performance. New York: Free Press.

Lukášová, R., Nový, I., et al. (2004). Organizační kultura: od sdilených hodnot a cilù k vyšší výkonnosti podniku. Praha: GRADA Publishing.

Martin, J., \& Felenz, M. (2010). Organizational Behaviour \& Management. Andover: Cengage Learning EMEA.

Matsumoto, D., \& Juang, L. (2007). Culture and Psychology. Belmont: WadsworthThomson Learning.

Minkov, M. (2007). What makes us different and similar: A new interpretation of the world values survey and other cross-cultural data. Sofia: Klasika Stil Publishing House.

Mitrovič, S., Grubič-Nešič, L., et al. (2014). Manager's Assessment of Organizational Culture. E\&M Ekonomie a Management, 17(3), 35-49. doi:10.15240/tul/001/2014-3-004.

Nový, I., \& Surynek, A. (2006). Sociologie pro ekonomy a manažery. Praha: Grada Publishing.

Olejárová, M., et al. (2007). Charakteristika vybraných krajín z pohladu interkultúrnej komunikácie. Banská Bystrica: Ekonomická fakulta Univerzity Mateja Bela $v$ Banskej Bystrici.

Organizačná štatistika 2014. (2014). Bratislava: Štatistický úrad SR. Retrieved from http://slovak.statistics.sk/.

Orieška, J. (2009). Vplyv globalizácie na vývoj organizovaného cestovného ruchu v Slovenskej republike. In M. Gúčik, et al. (Eds.), Cestovný ruch - teória a prax $v$ podmienkach globalizácie (pp. 131-147). Banská Bystrica: Ekonomická fakulta UMB.

Pichanič, M. (2004). Mezinárodní management a globalizace. Praha: C. H. Beck.

Průcha, J. (2010). Interkulturní komunikace. Praha: Grada Publishing.

Reisinger, Y. (2009). International Tourism. Cultures and Behavior. London and New York: Routledge, Taylor \& Francis Group.

Robbins, S.P., \& Coulter, M. (2004). Management. Praha: Grada Publishing.

Sackmann, S. (2006). Assessment, Evaluation, Improvement: Success through Corporate Culture. Gütersloh: Verlag Bertelsmann Stiftung.

Sagiv, L., \& Schwartz, S.H. (2007). Cultural values in organisations: insights for Europe. European Journal of International Management, 
1(3), 176-190. doi:10.1504/EJIM.2007.014698.

Sadri, H.A., \& Flammia, M. (2011). Interculural Communication. A New Approach to International Relations and Global Challenges. London: Continuum International Publishing Group.

Seková, M., et al. (2013). Manažment II, ludia $v$ organizácii a organizačná kultúra. Bratislava: IURA Edition.

Schein, E.H. (2010). Organizational Culture and Leadership. San Francisco: Jossey-Bass.

Schimmoeller, L. (2010). Leadership Styles in Competing Organizational Cultures. Leadership Review, 10(2), 125-141.

Šigut, Z. (2004). Firemni kultura a lidské zdroje. Praha: ASPI.

Teo, P., Hiong Li, L. (2003). Global and Local Interactions in Tourism. Annals of Tourism Research, 30(2), 287-306. doi:10.1016/S01607383(02)00049-X.

Trompenaars, F., \& Hampden-Turner, C. (2007). Riding the Waves of Culture: Understanding Diversity in Global Business. New York: McGraw-Hill.

Tsui, A.S., Nifadkar, S.S., \& Ou, A.Y. (2007). Cross-National, Cross-Cultural
Organizational Behavior Research: Advances, Gaps, and Recommendations. Journal of Management, 33(3), 426-478. doi:10.1177/0149206307300818.

Tureac, C.E. (2005). The components of the organizational culture. Acta Universitatis Danubius: Oeconomica, 1(1), 77-91.

prof. Ing. Milota Vetráková, PhD. Matej Bel University in Banská Bystrica Faculty of Economics

Department of Tourism and Hospitality milota.vetrakova@umb.sk

Ing. Lukáš Smerek Matej Bel University in Banská Bystrica Faculty of Economics Department of Corporate Economics and Management lukas.smerek@umb.sk 


\title{
DIAGNOSING ORGANIZATIONAL CULTURE IN NATIONAL AND INTERCULTURAL CONTEXT
}

\author{
Milota Vetráková, Lukáš Smerek
}

Formation of companies with multinational management that act within multinational and transnational corporations is a result of the globalization process. The change in organizational culture and management system is caused by the global environment. Companies' management is changing from ethnocentric and polycentric to management without borders. To achieve greater efficiency in competing in the global market is the reason for this change. The management system is complex, because it is based on international cooperation and consists of international managerial teams. The level of intercultural socialization and our cultural awareness are predicted by the comparison and confrontation of differences in organizational culture and human resources development. The paper is focused on diagnosing of organizational culture in organizations operating in Slovakia. The survey was conducted in 236 medium and large enterprises in Slovakia. Personnel or senior managers responsible for the level of organizational culture and human resources development in enterprises were the respondents. The assumptions about possibility of diagnosing the types of organizational culture in selected Slovak enterprises with and without foreign participation were confirmed. Pros and cons of different organizational culture types in the development of human resources were identified. We observed that hierarchical and clan cultures are the most common ones in Slovak enterprises. While hierarchical culture occurs in enterprises with no foreign participation, clan and market-oriented culture is strongly represented in enterprises with international participation. The results of organizational culture examination were confronted with the opinions of experts using the Delphi method leading to increasing the validity and reliability of the primary findings. Such opinions suggest links between the management of Slovak enterprises and national history and culture. Focus on flexibility, mutual communication, profitability and competitiveness is set in enterprises with international participation with influences of different cultures.

Key Words: Intercultural environment, organizational culture, diagnosing of culture, human resources development methodology of the research.

JEL Classification: M15.

DOI: 10.15240/tul/001/2016-1-005 